\title{
Anatomical Variations in Chronic Otitis Media Surgery; Comparison of Tomography and Perioperative Findings
}

\author{
Kronik Otitis Media Cerrahisinde Anatomik Varyasyonlar; \\ Tomografi ve Perioperatif Bulguların Karşılaştırılması
}

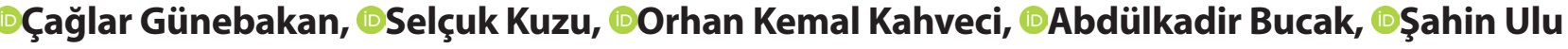

Afyonkarahisar Health Sciences University School of Medicine Department of Otorhinolaryngology Head and Neck Surgery, Afyonkarahisar, Turkey

\begin{abstract}
Aim: For a correct and adequate chronic otitis media surgery, it is necessary to define the anatomical structures correctly and to know their variations, otherwise, an increase in the complication rate is inevitable. This study aims to present the anatomical variations detected both in preoperative computerized tomography scanning and during operation, and complication rates encountered in 308 patients who underwent tympanomastoidectomy because of chronic otitis media in the light of current literature knowledge.
\end{abstract}

Material and Method: In this retrospective study, the files of 308 patients who underwent tympanomastoidectomy because of chronic otitis media in a tertiary clinic between September 2011 and July 2019 were scanned for encountered anatomical variations detected both in preoperative computerized tomography scanning and during operation and complications.

Results: There was Körner septum in 12 (3.8\%) cases, dehiscence in the facial nerve tympanic segment in 12 (3.8\%) cases, and lateral semicircular canal dehiscence (LSCD) in 4 (1.3\%) cases. In 4 (1.3\%) cases, we observed the dura was located downward and in 6 (1.9\%) cases, the sigmoid vein was located anterosuperiorly.

Conclusion: Always being careful in terms of anatomical variations and complications during the operation will increase the success of the surgery. Knowing the anatomical variations and complications related to the temporal region is of great importance for clinicians dealing with ear surgery.

Keywords: Chronic otitis media, anatomical variation, tympanomastoidectomy, cholesteatoma
Öz

Amaç: Doğru ve yeterli bir kronik otitis media cerrahisi için anatomik yapıların doğru tanımlanması ve olası varyasyonlarının bilinmesi gereklidir, aksi takdirde komplikasyon oranının artması kaçınılmazdır. Bu çalışmada hem preoperatif bilgisayarlı tomografi taramasında hem de operasyon sırasında saptanan anatomik varyasyonları ve kronik otitis media nedeniyle timpanomastoidektomi uygulanan 308 hastada karşılaşılan komplikasyon oranlarını güncel literatür bilgileri ışığında sunmayı amaçladık.

Gereç ve Yöntem: Bu retrospektif çalışmada, Eylül 2011-Temmuz 2019 tarihleri arasında üçüncü basamak bir klinikte kronik otitis media nedeniyle timpanomastoidektomi uygulanan 308 hastanın dosyaları, karşılaşılan anatomik varyasyonlar açısından hem ameliyat öncesi bilgisayarlı tomografi taramasında hem de ameliyat sırasında not edilen bulgular ve komplikasyonlar açısından tarandı.

Bulgular: 12 (\%3,8) olguda Körner septum, 12 (\%3,8) olguda timpanik segmentte fasiyal dehissans ve $4(\% 1,3)$ olguda lateral semisirküler kanal dehissansı (LSCD) vardı. 4 (\%1,3) olguda duranın aşağı, $6(\% 1,9)$ olguda sigmoid venin anterosuperior yerleşimli olduğu görüldü.

Sonuç: Operasyon sırasında anatomik varyasyonlar ve olası komplikasyonlar açıından her zaman dikkatli olmak ameliyatın başarısını artıracaktır. Temporal bölgeyle ilgili anatomik varyasyonların ve komplikasyonların bilinmesi kulak cerrahisi ile uğraşan klinisyenler için büyük önem taşımaktadır.

Anahtar Kelimeler: Kronik otitis media, anatomik varyasyon, timpanomastoidektomi, kolesteatom

Corresponding (İletişim): Selçuk Kuzu, Afyonkarahisar Health Sciences University School of Medicine Department of Otorhinolaryngology Head and Neck Surgery, Afyonkarahisar, Turkey

E-mail (E-posta): dr.selcukkuzu@hotmail.com

Received (Geliș Tarihi): 29.12.2020Ａccepted (Kabul Tarihi): 12.10.2021 


\section{INTRODUCTION}

Chronic inflammation and infection of the middle ear and mastoid spaces characterize chronic otitis media (COM). Its main clinical findings are membrane perforation, intermittent or continuous discharge, and hearing loss. While the inactive type of COM, which has various forms, can be controlled with topical treatment, the active and cholesteatoma types are destructive and complicated. Surgery is the only treatment option for the eradication of cholesteatoma and to avoid the complications of COM. ${ }^{[1]}$ The decision for the choice of surgical technique, preservation of higher hearing threshold, and prevention of complications such as infection, cerebral hernia, recurrence, and treatment failure is of particular importance. Computed tomography imaging of the temporal bone has been a standard procedure before surgery. CT reveals not only the extent of the pathologic process in the tympanic cavity and mastoid bone, but also shows potential complications and ossicular chain destruction. ${ }^{[2,3]}$ In COM surgery, infected mastoid cells are usually cleaned by performing tympanomastoidectomy. For a correct and adequate tympanomastoidectomy, it is necessary to define correctly the anatomical structures and to know their variations, otherwise, an increase in the complication rate is inevitable. In this study, we present the anatomical variations detected both in preoperative computerized tomography scanning and during operation, and complication rates encountered in 308 patients who underwent tympanomastoidectomy because of chronic otitis media in the light of current literature knowledge.

\section{MATERIAL AND METHOD}

The study was carried out with the permission of Afyonkarahisar Health Sciences University, Clinical Research Ethics Committee (Date: 06.11.2020, Decision No: 2011-KAEK2). All procedures were carried out in accordance with the ethical rules and the principles of the Declaration of Helsinki.

In this retrospective study, we scanned the files of 308 patients who underwent tympanomastoidectomy because of COM in a tertiary clinic between September 2011 and July 2019. Age, gender, complaints, history, physical examinations, and operation notes of all patients were scanned and recorded. Preoperative non-contrast temporal highresolution computerized tomography (CT) was performed in all patients enrolled in the study in an average timeline of 1 week to 1 month before surgery. Patients included in the study had high-resolution temporal bone sections with a 6th generation 6-row spiral multi-slice CT device branded "Philips Brilliance 6 Amsterdam, The Netherlands" at the Department of Radiology of the same tertiary hospital. Images were taken as $120 \mathrm{kV}, 200 \mathrm{mAs} /$ section, collimation $6 \times 0.75$, pitch 0.417 , rotation time $0.75 \mathrm{sec}$, image thickness $200 \mathrm{~mm}$, matrix 512 thickness. The radiology department evaluated and reported findings of tomography images. Patients who were operated on for chronic otitis media but did not undergo mastoidectomy or atticotomy, and who underwent revision surgery, were excluded. The anatomical variations detected during the surgery and the high-resolution temporal bone CT findings got preoperatively were compared. We noted the intraoperative complications. All the participants gave verbal and written informed consent before the operation.

\section{RESULTS}

157 (51\%) of the patients were female and 151 (49\%) were male. The average age was 36 (8-72). 36 of the operations performed on the patients were radical mastoidectomy, 103 were modified radical mastoidectomy, 42 were tympanoplasty, and simple mastoidectomy, 27 were inside out atticotomy. During the operation, we detected cholesteatoma in the middle ear in 190 (62\%) patients. We detected soft tissue in the middle ear or mastoid in these patients. As we encountered perioperatively anatomical variations; there was Körner septum in 12 (3.8\%) cases, dehiscence in the facial nerve tympanic segment in 12 (3.8\%) cases, and lateral semicircular canal dehiscence (LSCD) in 4 $(1.3 \%)$ cases. In $4(1.3 \%)$ cases, we observed the dura was located downward and in $6(1.9 \%)$ cases the sigmoid vein was located anterosuperiorly. (Table 1) Upon review of preoperative CT reports; Körner septum was noted in 10 of 12 cases, dehiscence in the facial nerve was noted in 5 of 12 cases, LSCD was noted in 1 of 4 cases, downward located dura was noted in all 4 cases and anterosuperiorly located sigmoid vein was also noted in all 6 cases, respectively.(Figure 1,2,3) When the ossicular status of patients was examined during operation, we saw ossicular destruction in the incus in 259 patients (84\%). Considering the tomography findings, the most ossicular destruction was seen in the incus of 210 patients (68\%). Malleus was detected as destructed in 120 patients (38\%) on CT and 166 patients (53\%) in operation. Stapes was detected as destructed in 118 patients (38\%) on CT and 102 patients (33\%) in operation. According to the operation records, complications developed in 10 patients. When complications are examined; Two cases had stapes subluxation and perilymph leakage. We repaired perilymph leakage with perichondrium and cartilage fragments. In 4 of the cases, cerebrospinal fluid leakage occurred because of dura damage, and the damage was repaired. In one of these 4 cases, the dural plateau was exposed because of dehiscence, while in one, the dural plateau was located downward.

\begin{tabular}{lc} 
Table 1. Anatomical variations and complications detected in the operation \\
Variations & $\begin{array}{c}\text { Number } \\
\text { of } \\
\text { patients }\end{array}$ \\
\hline Körner septum & $12(3.8 \%)$ \\
Dehiscence of the facial nerve tympanic segment & $12(3.8 \%)$ \\
Lateral semicircular canal dehiscence & $4(1.3 \%)$ \\
Downward located dura & $4(1.3 \%)$ \\
Anterosuperiorly located sigmoid vein & $6(1.9 \%)$ \\
\hline
\end{tabular}




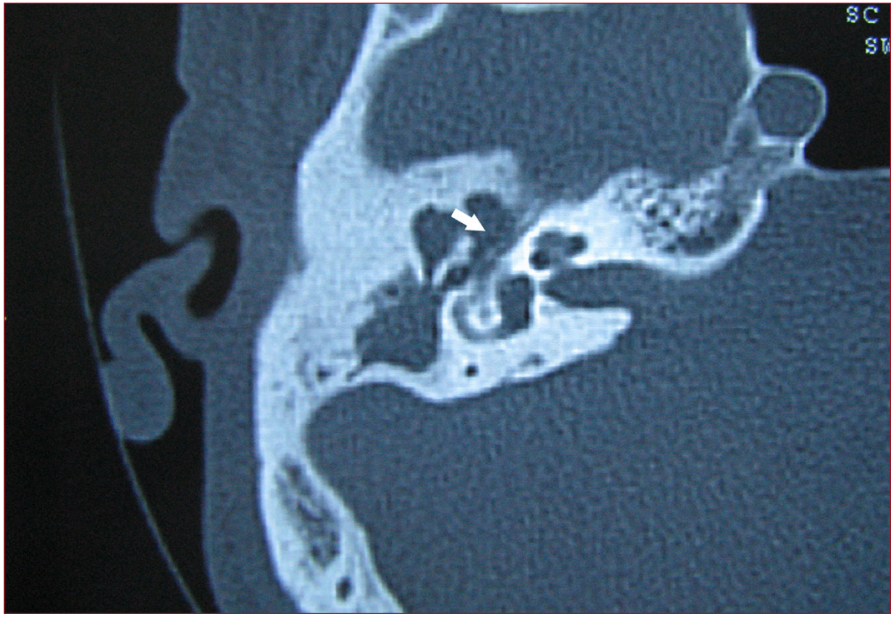

Figure 1. CT image. Dehiscence of the facial nerve tympanic segment, white arrow

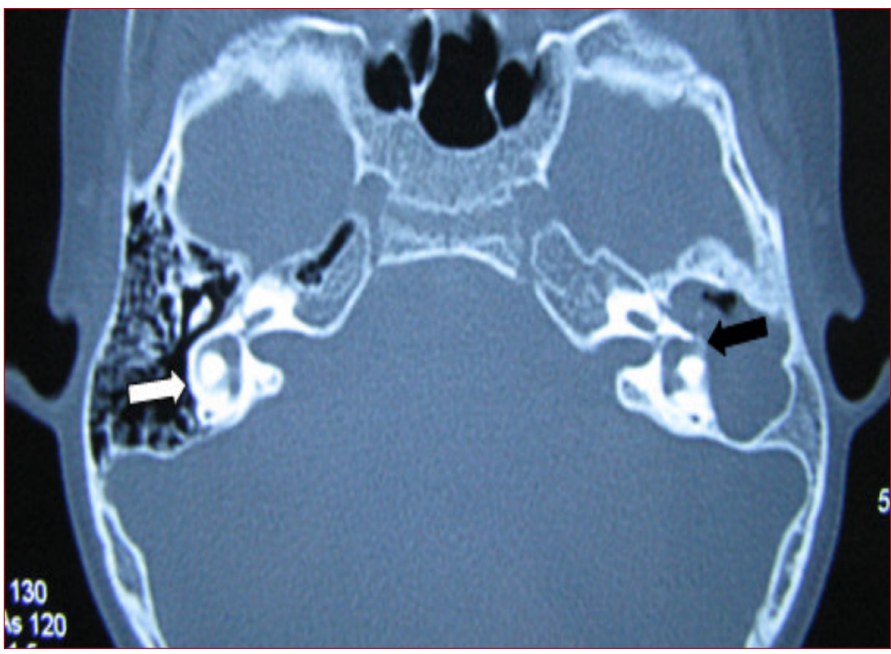

Figure 2. CT image.Lateral semicircular canal (LSSC), axial section, the white arrow: Right intact LSSC, Black arrow: Left LSSC dehiscence

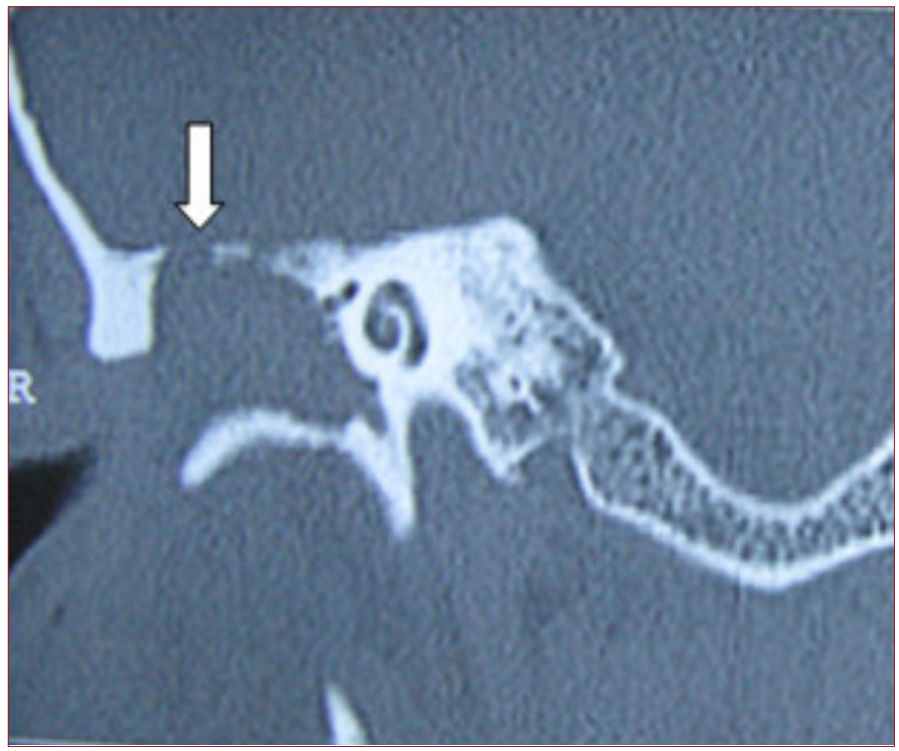

Figure 3. $\mathrm{CT}$ image. Dural bone defect (tegmen tympani), the white arrow (Coronal section, right ear)

\section{DISCUSSION}

Chronic otitis media (COM) is an inflammatory process in the middle ear that lasts longer than 3 months and is not completely cured by medical treatment, characterized by eardrum perforation, ear discharge, hearing loss. ${ }^{[4]} \mathrm{COM}$ is a middle ear disease that is characterized by inflammation characterized clinically by ossicular destruction. Ossicular resorption in COM with cholesteatoma is more serious than COM without cholesteatoma. In $80 \%$ of COMs with cholesteatoma, ossicular chain erosion is observed, while in non-cholesteatoma COM this rate decreases to $10-20 \%$. ${ }^{[5]}$ Many mechanisms related to osteoporosis in COM have been reported. These mechanisms are; chronic osteomyelitis, osteoclastic osteolysis, pressure necrosis, osteocytic osteolysis, melting through monocyte, melting through collagenase, acid phosphatase, and lysozyme, local pH changes, and vascular proliferation. These factors can lead to ossicular erosion, individually, or in combination. Ossicular resorption is one of the most important processes of COM. Because medical treatment can not control it. Besides, mostly conductive type, sensorineural hearing loss, and temporal bone and intracranial complications occur because of ossicular erosion. ${ }^{[6]}$

The Körner septum is a remnant of petrosquamous sutures. The incidence varies between $6.6 \%$ and $22.7 \%$. If a Körner septum is encountered while working with a drill to find the antrum, an ineffective mastoidectomy is performed by leaving the rest of the infection uncleaned, considering that the antrum was reached by mistake..$^{[7]}$ Some studies have reported that the Körner septum causes atypical blockage and causes chronic middle ear infections. ${ }^{[8]}$

Congenital type of facial canal dehiscence can be up to $55 \%$ in normal temporal bones, and over $90 \%$ of them are just above the oval window and be less than $1 \mathrm{~mm}$ in size. ${ }^{[9]}$ We know that most of the iatrogenic facial nerve injuries are caused by the poor understanding of intraoperative cue points, rather than the congenital anomaly of the facial canal or its secondary clearance to COM. The facial nerve injury rate was reported to be $0.6-3.6 \%$ during middle ear surgery. ${ }^{[0]}$ In a study, $55 \%$ of facial nerve dehiscence was encountered in 535 temporal bones. Facial canal dehiscences secondary to COM are approximately $80 \%$ in tympanic and proximal mastoid segment localization. ${ }^{[1]]}$ To avoid facial paralysis, which is important morbidity for the patient, the surgeon should not completely rely on $\mathrm{CT}$, but if dehiscence or a close relationship of the disease with the facial nerve is reported on $\mathrm{CT}$, we should take this point into consideration.

LSC dehiscence is seen in approximately $10 \%$ in COM with cholesteatoma. It is more common in recurrent and residual disease. In long-term COM cases; If vestibular symptoms and sensorineural hearing loss are present, erosion is expected in the otic capsule. The labyrinthine fistula is most commonly encountered in the lateral semicircular canal anterior convexity. ${ }^{[12]}$ 
The low-lying temporal lobe dura may cause difficulty in approaching the antrum and epitympanum, especially in closed cavity techniques. While the thinned tegmen can be seen on computed tomography, the operation finding may be in contrast. The opposite is also true. While dehiscence is detected in the operation, the tegmen may appear intact radiologically. ${ }^{[12]}$ The thin bone lamella, which makes up the dural tegmen, is difficult to be assessed since it is difficult to distinguish the soft tissue right next to the lamella. ${ }^{[13]}$ Therefore, the surgeon should be cautious when evaluating this situation.

Another complication for ear surgery is sigmoid sinus injury. A sigmoid sinus with bluish reflection is encountered at the posterior border of the mastoidectomy cavity. ${ }^{[14]}$ Where the sigmoid sinus is located anteriorly, the chance of sigmoid sinus injury increases. The anteriorly located sigmoid sinus complicates the approach to the mastoid cavity and antrum. The sigmoid sinus is at risk of disease spread from neighboring mastoid cells. Sigmoid sinus wall erosion may occur and may become more susceptible to injury while cleaning infected soft tissues. ${ }^{[12]}$

\section{CONCLUSION}

The prerequisite for minimizing the complication rates in tympanomastoidectomy is to pay utmost attention to anatomical limits and markers, as in all surgical interventions. Even though we can make even though anatomical evaluations before the operation with computed tomography today, the findings of the tomography may not coincide with the findings of the temporal bone and especially in the presence of a cholesteatoma. Always being careful in terms of anatomical variations during the operation will increase the success of the surgery and decrease the complication rate. Knowing the anatomical variations and complications related to the temporal region is of great importance for clinicians dealing with ear surgery.

\section{ETHICAL DECLARATIONS}

Ethics Committee Approval: The study was carried out with the permission of Afyonkarahisar Health Sciences University, Clinical Research Ethics Committee (Date: 06.11.2020, Decision No: 2011-KAEK-2).

Informed Consent: Because the study was designed retrospectively, no written informed consent form was obtained from patients.

Referee Evaluation Process: Externally peer-reviewed.

Conflict of Interest Statement: The authors have no conflicts of interest to declare.

Financial Disclosure: The authors declared that this study has received no financial support.

Author Contributions: All of the authors declare that they have all participated in the design, execution, and analysis of the paper, and that they have approved the final version.

\section{REFERENCES}

1. Mittal R, Lisi CV, Gerring R, et. al.Current concepts in the pathogenesis and treatment of chronic suppurative otitis media. J Med Microbiol 2015;64(10):1103-16.

2. Singh B, Maharaj TJ. Radical mastoidectomy: its place in otitic intracranial complications. J Laryngol Otol 1993;107:1113-8.

3. Aydil U, Köksal A, Özçelik T, Özgirgin N. Comparison of reformatted 2 D images with $3 \mathrm{D}$ reconstructions based on images from multi-detector CT of the temporal bone in operated COM patients. Int Adv Otol 2010;6:33741.

4. Qureishi A, Lee, Y, Belfield K, Birchall JP, Daniel M. Update on otitis mediaprevention and treatment. Infect Drug Resist 2014;7:15-24.

5. Kurihara A, Toshima M, Yuasa R, Takasaka T. Bone destruction mechanisms in chronic otitis media with cholesteatoma: specific production by cholesteatoma tissue in culture of bone-resorbing activity attributable to interleukin -1 alpha. Ann Otol Rhinol Laryngol 1991;100(12):989-98.

6. Macri JR, Chole RA. Bone Erosion in Experimental Cholesteatoma- the Effect of Implanted Barriers. Otolaryngol Head Neck Surg 1985;93(1):3-16.

7. Tos M, editor.In: Manual of middle ear surgery. New York, Thieme Medical Publishers;1995 pp 50-61.

8. Proctor B, Nielson E, Proctor C. Petrosquamosal suture and lamina. Otolaryngol Head Neck Surg 1981;89:124-9.

9. Djeric D, Savic D. Otogenic facial paralysis: A histopathological study. Eur Arch Otorhinolaryngol 1990;247:143-6.

10. Sezgin Z , Külekçi M . Kronik Otitis Mediada Kulak Zarı Perforasyonları ve Kemik Zincir Patolojileri ile İşitme Kayıpları arasındaki İlişki. J Contemp Med 2016; 6(4):266-76.

11. Sheehy JL, Brackmann DE, Graham MD. Cholesteatoma surgery: residual and recurrent disease. A review of 1,024 cases. Ann. Otol. Rhinol 1977;86(4 Pt 1):451-62.

12. Singh A, Thakur R, Kumar R, Verma H, Irugu D. Grading of the Position of the Mastoid Tegmen in Human Temporal Bones-A Surgeon's Perspective. J Int Adv Otol 2020; 16(1):63-6.

13. Walshe P, McConn Walsh R, Brennan P, Walsh M. The role of computerized tomography in the preoperative assessment of chronic suppurative otitis media. Clin Otolaryngol Allied Sci 2002;27:95-7.

14. Kizilay A, Aladag I, Cokkeser Y, Ozturan O. Dural bone defects and encephalocele associated with chronic otitis media or its surgery. Kulak Burun Bogaz Ihtis Derg 2002;9(6):403-9. 